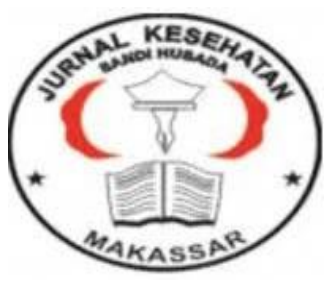

Jurnal Ilmiah Kesehatan Sandi Husada

hhttps://akper-sandikarsa.e-journal.id/JIKSH

Volume 9 Nomor 2 Desember 2020, pp 646-653

p-ISSN: 2354-6093 dan e-ISSN: 2654-4563

DOI: $10.35816 /$ jiskh.v10i2.379

\title{
Perbedaan Hematokrit Darah Segar dan Darah Simpan (30 Hari) di UTD RSAM Bandar Lampung
}

Difference between Hematocrit of Fresh Blood and Save Blood (30 Days) at UTD RSAM Bandar Lampung

\author{
Syuhada ${ }^{1}$ Aditya $^{2}$, Ira Candrawijaya ${ }^{3}$ \\ ${ }^{1}$ Departemen Patologi Klinik Fakultas Kedokteran Universitas Malahayati \\ ${ }^{2}$ Dosen Fakultas Kedokteran Universitas Malahayati \\ ${ }^{3}$ Program Studi Kedokteran Fakultas Kedokteran Universitas Malahayati
}

\section{Artikel info}

Artikel history:

Received; Juni 2020

Revised: Juli 2020

Accepted;Juli 2020

\begin{abstract}
Abstrak
Latar Belakang: pada saat pengambilan darah eritrosit akan mengalami kerusakan, setiap hari viabilitas eritrosit menjadi terus menurun akibat dari penurunan kadar ATP (Adenosin Trifosfat), sehingga apabila kadar ATP menurun maka terjadinya kehilangan lipid membran, membrane menjadi kaku dan bentuknya dari cakram menjadi sferis (tidak central polar dan ukuran kecil). Penelitian ini ditujukan untuk mengetahui perbedaan nilai hematokrit darah segar dengan darah simpan (30 hari) di UTD RSUD Dr. H. Abdul Moeloek Lampung tahun 2020. Metode: Jenis penelitian yang digunakan dalam penelitian ini adalah kuantitatif observasional dengan desain non probability sampling. Sampel yang digunakan pada penelitian ini responden yang bersedia mendonorkan darahnya di UTD RSUD Dr. H. Abdul Moeloek Lampung. Analisa data menggunakan rumus wilcoxon. Hasil: diperoleh $p$ value $>0,05$ yang artinya tidak terdapat perbedaan yang signifikan antara darah segar dengan darah simpan (30 hari) di UTD RSUD Dr. H. Abdul Moeloek Lampung. Kesimpulan: pengelolaan darah donor dan kualitas darah donor di tempat tersebut dalam keadaan baik sehingga darah donor bias diberikan kepada resipen, tanpa memiliki perubahan komponen yang signifikan.
\end{abstract}

\section{Abstract.}

Background: at the time of erythrocyte blood collection will be damaged, every day the viability of erythrocytes continues to decrease due to decreased levels of ATP (Adenosine Triphosphate), so that if ATP levels decrease then the loss of membrane lipids, membrane stiffens and the shape of the discs into spherical (discs) not central polar and small size). This study aimed to determine the difference in the 
hematocrit value of fresh blood with blood storage (30 days) at UTD Dr. H. Abdul Moeloek Lampung in 2020. Method: The type of research used in this study is quantitative observational with non-probability sampling design. The sample used in this study was respondents who were willing to donate their blood at UTD RSUD Dr. H. Abdul Moeloek Lampung. Analysis of data using the Wilcoxon formula. Results: obtained $p$ value> 0.05 which means there is no significant difference between fresh blood and blood storage (30 days) at UTD Dr. H. Abdul Moeloek Lampung. Conclusion: donor blood management and donor blood quality at the site are in good condition so that donor blood can be given to recipients, without having significant component changes.

\section{Keywords:}

Donor;

Blood;

Hematocrit;
Coresponden author:

Email: iracandrawijaya@gmail.com

artikel dengan akses terbuka dibawah lisensi CC BY 4.0

\section{Pendahuluan}

Darah adalah cairan yang beredar melalui jantung, arteri, kapiler, dan vena yang berfungsi mengangkut nutrien dan oksigen menuju sel-sel tubuh, serta berperan untuk mengeluarkan produk sisa dan karbon dioksida yang didalamnya terdapat bagian cair yaitu plasma, dan unsur-unsur padat seperti eritrosit, leukosit dan trombosit (Firani, 2018). Lebih dari 99\% sel adalah eritrosit, hematokrit, atau packed cell volume. Hematokrit pada dasarnya mencerminkan presentase eritorsit di dalam volume darah total (Sherwood, 2001). Penentuan nilai hematokrit dalam laboratorium dilakukan dengan dua metode yaitu metode makrometode dan juga mikrometode. Penetapan hasil nilai hematokrit lebih singkat didapatkan pada metode mikrometode dari pada dengan makrometode yang membutuhkan waktu lebih lama. Nilai hematokrit biasanya digunakan untuk mengetahui ada tidaknya anemia dan digunakan untuk menghitung indeks eritrosit (Gandasoebrata, 2019).

Kebutuhan darah semakin meningkat di dunia dimana 1 dari 7 pasien yang masuk rumah sakit memerlukan transfusi darah. Setiap hari kebutuhan darah di negara seperti Amerika Serikat sekitar 36.000 unit sel darah merah, 7.000 unit trombosit, dan 10.000 unit plasma. Hampir 21 juta komponen darah transfusi yang dibutuhkan pertahun. Setiap tahun, sekitar 6,8 juta orang menyumbangkan darahnya. Namun hanya 13,6 juta darah utuh dan darah merah yang terkumpul setiap tahunnya. Jumlah penduduk di Amerika Serikat sebanyak 328.200 jiwa. Sehingga masi terdapat kekurangan sebanyak 35,2\% atau 7,4 juta komponen darah lagi. Terdapat $10 \%$ dari populasi yang memenuhi syarat benar-benar mendonor darah setiap tahun, meskipun diperikirakan 38\% dari populasi Amerika Serikat memenuhi syarat untuk mendonor darah (Eder et al., 2008). Di indonesia jumlah donasi darah dalam 10 tahun terakhir terjadi peningkatan, tetapi belum dapat memenuhi kebutuhan. Produksi darah (WB dan komponen darah) pada tahun 2016 sebanyak 4.201.578 kantong. Sesuai dengan padoman dari WHO bahwa kebutuhan darah minimal 2\% dari jumlah penduduk, maka jika jumlah penduduk di Indonesia pada tahun 2016 sebanyak 258.704.986 jiwa, maka seharusnya dibutuhkan darah sebanyak 5.174.100 kantong darah, sehingga masih terdapat kekurangan sebesar 18,8\% atau sebanyak 972.522 kantong darah lagi (Kemenkes, 2014). 
Pada saat transfusi darah terdapat beberapa komponen seperti darah utuh WB (whole blood), darah merah utuh PRC (Packed Red Cell), plasma segar beku FFP (Fresh Frozen Plasma), AHF (Anti Hemophilic Factory) dan trombosit pekat TC (Thrombocyte Concentrate)(Kemenkes, 2014). Whole blood merupakan komponen darah yang utama. Dengan komposisinya terdiri dari eritrosit, plasma, leukosit, dan trombosit (Hutomo, 2009).

Perlakuan darah dan komponen setelah dilakukannya transfusi darah dari tempat penyimpanan ke ruangan perawatan juga memerlukan perlakuan khusus, mulai dari penyimpanan berupa cool box dan ice pack yang dapat mempertahankan suhu optimal selama proses transportasi yaitu suhu 20-6oC untuk WB (Wahyuningsih, 2019). Penyimpanan darah harus dijaga pada suhu 20-6oC dengan tujuan untuk menjaga kemampuan darah dalam menyalurkan oksigen, dekstrose tidak cepat habis, dan mengurangi pertumbuhan bakteri yang mengkontaminasi darah yang disimpan. Batas penyimpanan sangat penting, karena eritrosit sangat sensitif terhadap pembekuan (Saragih, dkk, 2019).

Pada saat pengambilan darah eritrosit akan mengalami kerusakan, setiap hari viabilitas eritrosit menjadi terus menurun akibat dari penurunan kadar ATP (Adenosin Trifosfat), sehingga apabila kadar ATP menurun maka terjadinya kehilangan lipid membran, membrane menjadi kaku dan bentuknya dari cakram menjadi sferis (tidak central polar dan ukuran kecil), hal tersebut selanjutnya akan menyebabkan kalium keluar dan natrium masuk ke sel (Saragih et al., 2019). Menurut penelitian yang dilakukan oleh (Afiyanti, 2017) yang melakukan penelitian pada November 2016 - Juni 2017 di Jombang, menyatakan bahwa hasil penelitian tersebut terdapat perbedaan yang signifikan antara nilai hematokrit yang ditunda 0 jam dan 6 jam mulai dari pengambilan sampel darah vena. Perbedaan tersebut dipengaruhi oleh umur, jenis kelamin, konsumsi obat antibiotik dan menstruasi (Syafikriatillah et al., 2016).

Sedangkan menurut penelitian yang dilakukan (Saragih et al., 2019) yang melakukan penelitian pada bulan Desember 2017 - Maret 2018 di RSUP H. Adam Malik Medan, bahwa tidak terjadi perubahan hematokrit yang signifikan tetapi masih dalam batas normal yang disimpan selama 7 hari. Kondisi ini dikarenakan hematokrit adalah fungsi dari hemoglobin. Terjadinya peningkatan hematokrit kemungkinan disebabkan oleh penurunan kadar ATP. Selama penyimpanan kadar ATP yang menurun mengakibatkan kerusakan lipid membrane, membrane menjadi kaku dan mengakibatkan terperangkapnya plasma. Berdasrkan fenomena dan data di atas maka penulis tertarik ingin membuktikan kebenaran penelitian tentang Perbedaan Nilai Hematokrit Antara Darah Segar dan Darah Simpan (30 Hari) di Unit Transfusi Darah RSUD. Dr. H Abdul Moeloek Bandar Lampung tahun 2020.

\section{Metode}

Jenis penelitian yang digunakan dalam penelitian ini adalah penelitian kuantitatif observasional dengan pendekatan cross sectional (Syahdrajat, 2019). Penelitian ini dimulai dari bulan Juni - Juli 2020 bertempat di UTD RSUD Dr. H. Abdoel Moeloek Lampung setelah mendapatkan ethical clearance dari Universitas Malahayati. Populasi yang digunakan dalam penelitian ini adalah subjek penelitian yang bersedia mendonorkan darahnya di Unit Transfusi Darah RSUD Dr.H Abdul Moeloek Bandar Lampung tahun 2020 yang berjumlah sebanyak 15 orang. Pada penelitian ini teknik pengambilan sampel menggunakan teknik Non Probablity Sampling (tidak secara acak) 
dan menggunakan teknik Convenience dari responden yang bersedia mendonorkan darahnya.

Alat yang digunakan untuk mendukung penelitian berupa hasil laboratorium darah lengkap di Unit Transfusi Darah di RSUD Dr. H Abdul Moeloek Bandar Lampung. Instrumen dalam penelitian ini adalah hasil laboratorium itu sendiri yang terdiri dari variabel independen dan dependen. Pada penelitian ini menggunakan Analisis univariat digunakan bertujuan untuk menjelaskan atau mendeskripsikan karakteristik setiap variabel penelitian. Analisis ini bertujuan untuk menganalisis variabel berupa variabel bebas yaitu Kadar hematocrit darah segar serta variabel terikat yaitu kadar hematocrit darah simpan (30 hari). Penelitian ini juga menggunakan uji statistis yaitu uji Analisisis bivariat digunakan untuk mengetahui hubungan antara variabel dependen dan independen dengan menggunakan uji statistik. Uji statistik yang digunakan dalam penelitian ini adalah Uji Wilcoxon. Uji Wilcoxon merupakan uji komparatif nonparametrik yang cukup sering digunakan dalam penelitian yang menggunakan dua variabel, dimana skala data kedua variabel adalah nominal.

Untuk menentukan signifikasi antara data yang diobservasi dengan data yang di harapkan dilakukan batas kemaknaan $(<0,05)$, dimana dinyatakan memiliki hubungan yang bermakna apabila $\mathrm{p} \leq 0,05$ dan dinyatakan tidak memiliki hubungan yang bermakna apabila $\mathrm{p}>0,05$

Hasil Dan Pembahasan

Tabel .1 Distribusi Frekuensi Karakteristik Responden

\begin{tabular}{lcc}
\hline Jenis Kelamin & Frekuensi & Persentase (\%) \\
\hline Laki-laki & 11 & 73,3 \\
Perempuan & 4 & 26,7 \\
\hline Total & 15 & 100,0 \\
\hline Usia & 2 & 13,3 \\
\hline 20 & 2 & 53,3 \\
\hline 21 & 8 & 20,0 \\
\hline 22 & 3 & 6,7 \\
\hline 23 & 1 & 0 \\
\hline 24 & 0 & 0 \\
\hline 25 & 0 & 0 \\
\hline 26 & 0 & 6,7 \\
\hline 27 & 1 & 0 \\
\hline 28 & 0 & 0 \\
\hline 29 & 0 & 0 \\
\hline 30 & 0 & 100,0 \\
\hline Total & 15 & 26,7 \\
\hline Golongan Darah & & 26,7 \\
\hline A & 4 & 26,7 \\
\hline AB & 4 & 20,0 \\
\hline 0 & 4 & 100,0 \\
\hline Total & 3 & \\
\hline
\end{tabular}


Tabel 2 Distribusi Frekuensi Nilai Hematokrit Darah Segar dan Darah Simpan

\begin{tabular}{cccc}
\hline $\begin{array}{c}\text { Jenis } \\
\text { Kelamin }\end{array}$ & $\begin{array}{c}\text { Persentase Nilai } \\
\text { Hematokrit Darah } \\
\text { Segar (\%) }\end{array}$ & $\begin{array}{c}\text { Persentase Nilai } \\
\text { Hematokrit Darah } \\
\text { Simpan (\%) }\end{array}$ & $\begin{array}{c}\text { Rerata Penurunan } \\
\text { Nilai } \\
\text { Hematokrit/Hari }\end{array}$ \\
\hline \multirow{4}{*}{ Perempuan } & 32 & 18 & $-0,46$ \\
& 35 & 36 & 0,03 \\
& 35 & 38 & 0,1 \\
& 36 & 40 & 0,13 \\
\hline & 48 & 43 & $-0,16$ \\
& 44 & 39 & $-0,16$ \\
Laki-laki & 44 & 41 & $-0,1$ \\
& 41 & 38 & $-0,1$ \\
& 45 & 43 & $-0,06$ \\
& 45 & 44 & $-0,03$ \\
& 41 & 42 & 0,03 \\
& 38 & 41 & 0,1 \\
& 41 & 44 & 0,1 \\
& 41 & 45 & 0,13 \\
\hline Rata-rata & 40 & 44 & 0,13 \\
\hline
\end{tabular}

Tabel.3 Uji Normalitas Shapiro-Wilk Nilai Hematokrit Darah Segar dan Darah Simpan

\begin{tabular}{lcc}
\hline & & $\boldsymbol{P}$-Value \\
\hline $\begin{array}{l}\text { Nilai Hematokrit Darah Segar } \\
\text { Nilai Hematokrit Darah Simpan }\end{array}$ & & 0.694 \\
& $\mathbf{N}$ & 0.000 \\
\hline $\begin{array}{l}\text { Darah Segar } \\
\text { Darah Simpan }\end{array}$ & 15 & $\boldsymbol{P}$-Value \\
\hline
\end{tabular}

Berdasarkan tabel 2 diketahui bahwa dari 15 responden yang diteliti, terlihat bahwa distribusi frekuensi pasien yang memiliki nilai hematokrit pada darah segar paling tinggi yakni $48 \%$ dan paling rendah sebesar 32\%. Sementara itu, dari nilai hematokrit pada darah simpan paling tinggi sebesar $45 \%$ dan paling rendah sebesar $18 \%$.

Sebagaimana terlihat dari uji analisis di atas, diperoleh p-value antara darah segar dengan darah simpan sebesar 0,909 (p-value>0,05). Dapat disimpulkan bahwasannya tidak terdapat perbedaan yang signifikan antara nilai hematokrit darah segar dengan darah simpan (30 hari) di UTD RSUD Dr. H. Abdul Moeloek Bandar Lampung tahun 2020. Hal ini berarti hipotesis yang dikemukakan ditolak (tabel.3)

Darah merupakan cairan yang beredar melalui jantung, arteri, kapiler, dan vena yang berfungsi mengangkut nutrien dan oksigen menuju sel-sel tubuh, serta berperan untuk mengeluarkan produk sisa dan karbon dioksida yang didalamnya terdapat bagian cair yaitu plasma dan unsur-unsur padat seperti eritrosit, leukosit, dan trombosit (Eder et al., 2008). Hematokrit pada dasarnya mencerminkan persentase eritrosit di dalam volume darah total (Sherwood, 2001). Nilai hematokrit biasanya digunakan untuk mengetahui ada 
tidaknya anemia dan digunakan untuk menghitung indeks eritrosit(Gandasoebrata, 2019). Menurut hasil penelitian (Pambudi, 2020) kadar feritin dengan kreatinin serum pada anak Thalassemia B Mayor. Nilai hematokrit merupakan volume semua eritrosit dalam $100 \mathrm{ml}$ darah yang dinyatakan dalam persen (\%), biasanya ditentukan dengan darah kapiler dan vena. Nilai ini dapat dinyatakan sebagai persentase (konvensional) atau sebagai pecahan desimal (unit SI), dan liter/liter (L/L). Nilai normal hematokrit pada laki-laki berbeda dengan wanita. Nilai hematokrit pada laki-laki yaitu 40-48\% sedangkan pada wanita 37$43 \%$. Umumnya nilai hematokrit pada wanita lebih rendah dari pada laki-laki (Gandasoebrata, 2019). Nilai hematokrit yang dinyatakan g/L adalah sekitar tiga kali kadar $\mathrm{Hb}$. Nilai hematokrit menunjukkan kekentalan darah yang sebanding dengan oksigen yang dibawanya (Kiswari, 2014).

Secara umum, nilai hematokrit dapat dipengaruhi oleh dua faktor utama, yakni faktor in vivo (eritrosit, viskositas darah, dan plasma) dan faktor in vitro (pemusingan/sentrifugasi, antikoagulan, suhu dan waktu penyimpanan sampel, bahan pemeriksaan, keadaan tabung, pembacaan yang tidak tepat, dan bahan darah yang digunakan) (Gandasoebrata, 2019). Hal ini menyebabkan perlakuan darah dan komponen setelah dilakukan transfusi darah dari tempat penyimpanan ke ruangan perawatan memerlukan perlakuan khusus, mulai dari penyimpanan berupa cool box dan ice pack yang dapat mempertahankan suhu optimal selama proses transportasi yaitu suhu 2o-6oC untuk WB. Penyimpanan darah harus dijaga pada suhu 20-6oC dengan tujuan untuk menjaga kemampuan darah dalam menyalurkan oksigen, dekstrose tidak cepat habis, dan mengurangi pertumbuhan bakteri yang mengkontaminasi darah yang disimpan. Batas penyimpanan sangat penting, karena eritrosit sangat sensitif terhadap pembekuan (Saragih et al., 2019)Apabila dilakukan perlakuan yang tepat, darah tidak akan mengalami perubahan yang signifikan, sehingga darah transfusi dapat diberikan kepada resipen agar dapat digunakan sebagaimana mestinya.

Berdasarkan data dari penelitian yang dilakukan, hasil analisa data tersebut didukung oleh beberapa penelitian dan bertentangan dengan penelitian lainnya. Pada penelitian ini, terjadi penurunan nilai hematokrit per hari sebesar 0,03\% dengan perbedaan yang tidak signifikan antara darah segar dengan darah simpan. Menurut (Saragih et al., 2019), diperkirakan 1-5\% eritrosit menjadi rusak selama waktu pengambilan donor. Setiap hari viabilitas eritrosit menjadi terus menurun akibat dari penurunan kadar ATP (Adenosin Trifosfat), sehingga apabila kadar ATP menurun maka akan terjadi kehilangan lipid membran, membran menjadi kaku, dan bentuknya dari cakram menjadi sferis (tidak central polar dan ukuran kecil). Hal tersebut akan menyebabkan kalium keluar dan natrium masuk ke sel (Saragih et al., 2019). Hal ini menyebabkan eritrosit membengkak dan viskositas darah menjadi tinggi. (Afiyanti, 2017) Akan tetapi, bila berlangsung lama, hal di atas akan menyebabkan penurunan nilai hematokrit dikarenakan proses destruksi yang berlangsung. Akan tetapi, penurunan yang terjadi dalam penelitian ini masih dalam toleransi (dikarenakan perlakuan terhadap darah donor yang baik) sehingga darah tersebut masih dapat ditransfusikan kepada resipen.

Pada penelitian ini, terdapat beberapa komponen darah yang mengalami kenaikan hematokrit serta penurunan hematokrit. Berdasarkan analisis peneliti, hal ini mungkin terjadi dikarenakan antikoagulan yang tidak tercampur secara merata sehingga antikoagulan yang dilarutkan tidak homogen terutama pada sampel yang pertama. Selain itu, pada proses penelitian, tidak seluruh sempel diperiksa bersamaan karena waktu luang yang dimiliki responden berbeda. Sehingga dalam pengerjaannya tidak hanya dilakukan oleh satu orang laboran tetapi banyak laboran yang memiliki keterampilan masing-masing yang menyebabkan perbedaan perlakuan preanalitiknya. Pembacaan yang kurang tepat 
oleh laboran juga mungkin mempengaruhi hasil data penelitian ini. Hal-hal ini diduga dapat mengakibatkan adanya kenaikan hematokrit pada darah, akan tetapi penulis berasumsi apabila durasi penelitian diperpanjang, seluruh hasil hitung hematokrit akan mengalami penurunan. Penambahan sampel juga sebaiknya dilakukan demi meningkatkan akurasi hasil penelitian.

Sementara itu hasil penelitian ini berbeda dengan yang dikemukakan oleh (Afiyanti, 2017) yang menyatakan bahwa berdasarkan hasil analisis data penelitiannya didapatkan perbedaan yang signifikan antara nilai hematokrit yang ditunda 0 jam dengan 6 jam mulai dari pengambilan sampel darah vena. Afiyanti menyebutkan perbedaan tersebut dipengaruhi oleh umur, jenis kelamin, konsumsi obat antibiotik, dan menstruasi. Sedangkan penelitian yang dilakukan oleh (Saragih et al., 2019) menyatakan hasil yang berbeda dengan (Afiyanti, 2017). Hasil penelitian Saragih menunjukkan tidak terjadi perubahan hematokrit yang signifikan tetapi masih dalam batas normal yang disimpan selama 7 hari. Kondisi ini dikarenakan hematokrit adalah fungsi dari hemoglobin. Terjadinya peningkatan nilai hematokrit kemungkinan disebabkan oleh penurunan kadar ATP. Selama penyimpanan, kadar ATP yang menurun mengakibatkan kerusakan lipid membran, membran menjadi kaku dan mengakibatkan terperangkapnya plasma. Namun, apabila hal ini berlangsung lama, penurunan nilai hematokrit dapat terjadi akibat proses destruksi yang terjadi. Dengan bertambahnya waktu penyimpanan, akan terjadi perubahan-perubahan dalam komponen darah simpan, baik dalam komposisi maupun fungsinya. Pada darah segar fungsi eritrosit masih relatif baik. Setelah penyimpanan darah selama 14 hari dalam larutan ACD, hampir sebagian besar eritrosit hidup normal dalam sirkulasi darah resipien setelah ditransfusikan, sebagian kecil (kira-kira 10\%) tidak berfungsi lagi dalam 24 jam pertama. Kemudian pada hari berikutnya berkurang 1\% perhari.

\section{Simpulan Dan Saran}

Berdasarkan analisa dan pembahasan di atas, tidak terdapat perbedaan yang signifikan antara kadar hematocrit darah segar dengan kadar hematocrit darah simpan (30 hari) di URD Dr. H. Abdul Moeloek Lampung. Hal ini menunjukan bahwasannya pengelolaan darah donor dan kualitas darah donor di tempat tersebut dalam keadaan baik sehingga darah donor bias diberikan kepada resipen, tanpa memiliki perubahan komponen yang signifikan. Petugas Unit Transfusi Darah RSUD Dr. H. Abdoel Moeloek disarankan tetap mempertahankan standar proses transfusi dan penyimpnan darah sehingga mutu dan kualitas dari darah yang ditransfusi tetap terjaga. Penyimpanan darah yang dilakukan juga sebaiknya tidak terlalu lama, karena hal ini dapat mempengaruhi mutu dan kualitas dari darah tersebut.

Penelitian selanjutnya diharapkan dapat meneliti pengaruh darah donor dalam kantong darah yang dibiarkan dalam suhu ruangan terhadap hasil pemeriksaan eritrosit dan hematokrit. Penelitian selanjutnya juga diharapkan dapat meneliti pengaruh penyimpanan darah donor dengan waktu yang lebih lama. Sampel yang lebih banyak juga dapat dilakukan sehingga akurasi data hasil penelitian lebih baik. Penelitian lanjutan mengenai peningkatan kadar hematokrit antara sebelum dan sesudah transfusi juga dapat dilakukan dengan menggunakan desain atau metode penelitian yang berbeda. 


\section{Daftar Rujukan}

Afiyanti, F. F. (2017). Perbedaan Nilai Hematokrit Ditunda 0 Jam Dan 6 Jam Menggunakan Metode Mikrohematokrit (Studi Pada Mahasiswa Program Studi D-III Analis Kesehatan Semester IV-B STIKes ICMe Jombang). STIKES Insan Cendekia Medika Jombang.

Eder, A. F., Dy, B. A., Kennedy, J. M., Notari IV, E. P., Strupp, A., Wissel, M. E., ... Newman, B. H. (2008). The American Red Cross donor hemovigilance program: complications of blood donation reported in 2006. Transfusion, 48(9), 1809-1819.

Firani, N. K. (2018). Mengenali Sel-Sel Darah dan Kelainan Darah. Universitas Brawijaya Press.

Gandasoebrata, R. (2019). Penuntun laboratorium klinik.

Hutomo, S. (2009). Penelitian retrospektif penderita vitiligo di divisi kosmetik medik URJ kesehatan kulit dan kelamin RSUD Dr. Soetomo Surabaya Periode, 2011.

Kemenkes, P. (2014). Situasi Pelayanan Darah di Indonesia. Jakarta: Pusdatin Kemenkes.

Kiswari, R. (2014). Hematologi dan Transfusi. Jakarta: Erlangga.

Pambudi, M. (2020). Hubungan Antara Kadar Feritin Dengan Kreatinin Serum Pada Anak Thalasemia Mayor. Jurnal Ilmiah Kesehatan Sandi Husada, 11(1 SE-Articles). https://doi.org/10.35816/jiskh.v11i1.327

Saragih, P., Adhayanti, I., Lubis, Z., \& Hariman, H. (2019). Pengaruh waktu simpan Packed Red Cells (PRC) terhadap perubahan kadar hemoglobin, hematokrit, dan glukosa plasma di RSUP H. Adam Malik, Medan, Indonesia.

Sherwood, L. (2001). Fisiologi manusia dari sel ke sistem. Jakarta: EGC.

Syafikriatillah, A. R., Darwis, D., Abbas, B., Maheshwari, H., Noviana, D., Hewan, K., ... Barat, J. (2016). Profil Darah Putih Tikus Sprague Dawley Pascaimplantasi Tandur Tulang DFDBX Dan Membran Nata De Coco pada Defek Tulang Kalvaria. 1(September), 11109.

Wahyuningsih, S. (2019). Perbedaan Kadar Hemoglobin Dan Hematokrit Pada Produk Packed Red Cells Dengan Metoda Sedimentasi Dan Sentrifugasi Di UDD PMI Kota Surakarta. Universitas Setia Budi. 